\title{
Effect of finishing system on carcass characteristics and composition of Mubende goats and their Boer goat crossbreds
}

\author{
K. Kamatara ${ }^{1}$, D. Mpairwe ${ }^{1 \#}$, M. Christensen ${ }^{2}$, D. Mutetikka ${ }^{1}$ \& J. Madsen ${ }^{3}$ \\ ${ }^{1}$ Department of Agricultural Production, College of Agricultural and Environmental Sciences, Makerere University, \\ P.O. Box 7062 Kampala, Uganda. \\ ${ }^{2}$ Department of Food Science, University of Copenhagen, Frederiksberg C, Denmark. \\ ${ }^{3}$ Department of Large Animal Sciences, University of Copenhagen, Frederiksberg C, Denmark
}

(Received 22 June 2013; Accepted 2 September 2013; First published online 18 September 2013)

\begin{abstract}
Copyright resides with the authors in terms of the Creative Commons Attribution 2.5 South African Licence. See:
http://creativecommons.org/licenses/by/2.5/za/Condition of use: The user may copy, distribute, transmit and adapt the work, but must recognise the authors and the South African Journal of Animal Science
\end{abstract}

\begin{abstract}
A study was conducted to evaluate the influence of feeding systems on carcass characteristics and composition of Mubende goats and their Boer goat crossbreds. A $2 \times 3$ factorial arrangement was used to randomly allocate 60 castrates, 30 purebred Mubende and 30 Mubende x Boer, aged 9 - 12 months, to three feeding systems: sole grazing (T1), grazing + non-molasses based concentrate (T2) and grazing + a molasses based concentrate (T3). Carcass measurements included carcass weights, carcass length, internal chest width, hind-limb length and maximum hind limb width. Tissue composition was estimated using the $6^{\text {th }}$ rib. Crossbreds had heavier and longer carcasses $(23.1 \mathrm{~kg})$ and $(65.7 \mathrm{~cm})$ than the Mubende $(19.0 \mathrm{~kg}$ and 63.2 $\mathrm{cm})$, respectively. Crossbreds also had bigger hind quarters $(39.0 \mathrm{~cm})$ and higher blockiness $(0.38)$ indices than Mubende goats, $37.1 \mathrm{~cm}$ and 0.29 , respectively. Dissectible lean and fat percentages varied in an ascending order of $66 \%, 72 \%, 72.6 \%$ and $8 \%, 14 \%$ and $16.5 \%$ for $\mathrm{T} 1, \mathrm{~T} 2$ and $\mathrm{T} 3$, respectively. A reverse trend was observed for bone percentages with carcasses from $\mathrm{T} 1$ having higher bone percentage (18.1\%) than T2 (16.5\%) and T3 (16.1\%) irrespective of genotype. The study showed that supplementation of grazing goats has a great potential for goat meat production in Uganda.
\end{abstract}

Keywords: Carcass characteristics, composition, indigenous goats, supplementation

\#Corresponding author: dmpairwe@agric.mak.ac.ug

\section{Introduction}

The acceptability of a carcass lies in its perceived economic value, which depends on its potential to yield high quantities of meat (Mahgoub et al., 2012). Traits such as lean: bone ratio, confirmation, morphological measurements and the distribution of fat within the carcass are of great importance in meat production (Chacón et al., 2011; Simela et al., 2011). In Uganda, goat meat production relies on local, indigenous herds raised under traditional production systems. Under the traditional production system, goats are grazed on unimproved natural pastures whose supply fluctuates both in quality and quantity between dry and wet seasons. Consequently, goats brought to the market are of poor condition which gives rise to carcasses of low quality. Safari et al. (2009) noted that modifying traditional production systems through supplementation improves both composition and carcass quality of goats.

Earlier researchers, such as Devendra \& McLorey (1982), Okello \& Obwolo (1984) and FAO (2004), recognized the potential of Mubende goat as a meat producing breed; to date, however, no studies have been conducted to link animal breed and production system to carcass quality from Mubende goats. The few studies conducted to evaluate the potential of Mubende goats for improved meat production were only directed towards growth rates and carcass weights and did not consider composition (Okello et al., 2004). 
The main objective of this study was, therefore, to investigate the influence of feeding system on carcass characteristics and composition of Mubende goats and their Boer goat crossbreds.

\section{Materials and Methods}

A 2 x 3 factorial arrangement was used to randomly allocate 60 castrates between 9 - 12 months of age (31.3 $\pm 2.2 \mathrm{~kg}$ initial weight), 30 purebred Mubende $(\mathrm{M})$ and 30 Mubende $\mathrm{x}$ Boer (MxB) goats, to three feeding systems: sole grazing (T1), grazing + non-molasses based concentrate (T2) and grazing + molassesbased concentrate (T3). Grazing pastures comprised of Cymbopogon ssp., Themeda ssp., Bracharia ssp. and Panicum maximum. Maize bran, cotton seed cake and molasses purchased from Maganjo Grain Millers, Mukwano Oil processors and Kakira Sugar Works Ltd, respectively, were used to formulate two concentrates, i.e. a molasses-based and a non-molasses-based concentrate. Chemical composition of feeds and pastures is presented in Table 1. Concentrates were offered in the morning at 08:00 before the goats were released for grazing and at 18:00 when they returned from grazing. After 90 days of concentrate feeding, the goats were transported at 18:00 to the abattoir for slaughter. At the abattoir, the goats were left in the lairage for $12 \mathrm{~h}$ with access to fresh drinking water ad libitum.

Table 1 Chemical composition of feeds with standard deviation

\begin{tabular}{lccc}
\hline & Molasses concentrate & Maize concentrate & Pasture \\
\hline Dry matter (g/kg) & $901.0 \pm 3.4$ & $912.0 \pm 12.5$ & $825.0 \pm 8.3$ \\
Gross energy (MJ/kg DM) & $16.4 \pm 0.2$ & $16.6 \pm 1.0$ & $15.3 \pm 0.9$ \\
Crude protein (g/kg DM) & $164.1 \pm 9.0$ & $173.0 \pm 5.1$ & $90.0 \pm 11.9$ \\
Neutral detergent fibre (g/kg DM) & $377.0 \pm 12.1$ & $517.0 \pm 24.1$ & $558.1 \pm 2.7$ \\
Acid detergent fibre (g/kg DM) & $108.0 \pm 4.1$ & $107.3 \pm 10.1$ & $346.6 \pm 16.1$ \\
Acid detergent lignin (g/kg DM) & $27.4 \pm 06$ & $101.2 \pm 6.1$ & $59.2 \pm 5.4$ \\
Ether extract (g/kg DM) & $82.2 \pm 4.1$ & $4.2 \pm 0.6$ & $9.8 \pm 1.6$ \\
Ash (g/kg/DM) & $76.3 \pm 2.0$ & $91.2 \pm 5.1$ & $80.2 \pm 4.7$ \\
Calcium (g/kg DM) & $1.0 \pm 0.1$ & $0.9 \pm 0.01$ & $4.5 \pm 1.2$ \\
Phosphorus (g/kg DM) & $10.5 \pm 0.2$ & $11.5 \pm 0.8$ & $8.2 \pm 1.1$ \\
\hline
\end{tabular}

The goats were slaughtered without stunning; carcasses were weighed using a digital scale (SECO series, SECO Co, Kamapala Uganda) and taken to a chiller at $+4{ }^{\circ} \mathrm{C}$ when $\mathrm{pH}$ had fallen to 6.2. The $\mathrm{pH}$ was taken in the longissimus dorsi at the $10^{\text {th }}$ rib using a pH meter electrode (Knick, Elektronische MeBgeräte, $\mathrm{GmbH} \& \mathrm{Co}$.). Carcass morphological measurements were taken at $48 \mathrm{~h}$ post mortem according to De Boer et al. (1974). The following measurements were taken: Carcass length (measured from the cranial side of ischio-pubis symphysis to the middle of cranial edge of first rib), internal chest width (from the ventral edge of spinal canal at $5^{\text {th }}-6^{\text {th }}$ thoracic to the $6^{\text {th }}$ sternebra), hind-limb length (from the internal face of tarsometatarso joint to the cranial edge of ischio-pubis symphysis), and maximum hind limb width. Blockiness index (BI) was computed using the formula BI = Hot carcass weight/carcass length (Albertì et al., 2008). Carcass composition was estimated using the $6^{\text {th }}$ rib according to Robelin \& Geay (1974); the rib was dissected into individual components of subcutaneous fat, intramuscular fat, lean, bones and other tissues (e.g. ligaments, tendons). Results were expressed as percentages of the entire rib weight. Longissimus dorsi (LD) area was estimated according to Johnson \& Baker (1997). The transparency paper was cleaned and weighed to get its weight (W1), and its area (A1) was calculated from length and width. The traced area was cut out using and weighed to get weight (W2). The LD area (A2) was calculated as (A1 x W2/W1). Data were analysed using PROC GLM procedure of Statistical Analysis System (SAS, 2001). Differences were considered significant at $P<0.05$ and least square means were compared using the PDIFF of SAS. 


\section{Results and Discussion}

Crossbreds had longer carcasses $(P<0.05)$, with bigger hind limbs and higher blockiness indices (Table 2) than pure Mubende goats which could be attributed to the larger frame and mature size of Boer goats. Boer goats have large frame size and muscularity and were developed specifically for meat production purposes (Casey \& Webb, 2010; Steyn, 2010). On a percentage basis, there were no significant differences with regard to muscle percentage between the two genotypes. It should be noted that tissue distribution in both genotypes studied averaged at $70 \%$ lean, $17 \%$ bone and $13 \%$ fat. These values are within ranges reported for South African indigenous goats and other goat breeds (Devendra \& Owen, 1983, Simela et al., 2011). These results show that the indigenous Mubende goat has a high meat production potential and compares with its Boer crossbreds, one of the world's goat meat producing breeds.

Supplemented goats had higher carcass weights $(P<0.05)$, grades and blockiness indices than grazed goats. The observed heavier carcasses and higher blockiness indices exhibited by supplemented goats indicated greater muscular development and compactness than grazed goats. A study by Ryan et al. (2007) noted that feeding goats high energy diets resulted in heavier carcass weights, longer carcasses and more heavily muscled fatter carcasses than grazed goats.

Table 2 Effect of feeding on carcass characteristics and composition of Mubende (M) goats and their Boer goat crossbreds $(\mathrm{MxB})$

\begin{tabular}{|c|c|c|c|c|c|c|c|c|c|}
\hline \multirow{2}{*}{ Trait } & \multicolumn{3}{|c|}{$\mathbf{M}$} & \multicolumn{3}{|c|}{ MxB } & \multicolumn{3}{|c|}{ Significance } \\
\hline & $\mathrm{T} 1$ & $\mathrm{~T} 2$ & T3 & $\mathrm{T} 1$ & $\mathrm{~T} 2$ & T3 & SE & G & $\mathrm{T}$ \\
\hline \multicolumn{10}{|l|}{ Carcass characteristics } \\
\hline Carcass weight (kg) & $17.4^{\mathrm{a}}$ & $20.7^{\mathrm{bc}}$ & $19.9^{c}$ & $19.9^{\mathrm{c}}$ & $23.6^{\mathrm{d}}$ & $22.0^{\mathrm{bd}}$ & 0.7 & $* * *$ & $* * *$ \\
\hline Carcass grade & $4.7^{\mathrm{a}}$ & $5.7^{\mathrm{b}}$ & $5.4^{\mathrm{b}}$ & $5.0^{\mathrm{ba}}$ & $6.4^{\mathrm{c}}$ & $5.3^{\mathrm{b}}$ & 0.34 & $*$ & $*$ \\
\hline Carcass length (cm) & $64.0^{\mathrm{a}}$ & $63.5^{\mathrm{a}}$ & $63.5^{\mathrm{a}}$ & $65.9^{\mathrm{b}}$ & $65.7^{\mathrm{b}}$ & $65.6^{\mathrm{b}}$ & 1.02 & * & ns \\
\hline Chest width (cm) & $20.0^{\mathrm{a}}$ & 20.9 & 20.8 & 20.3 & 21.4 & 19.0 & 0.83 & ns & ns \\
\hline Hind leg length (cm) & $42.2^{\mathrm{a}}$ & 38.2 & 42.6 & 43.3 & 42.5 & 42.8 & 1.7 & ns & ns \\
\hline Hind leg width (cm) & $37.9^{\mathrm{a}}$ & $37.6^{\mathrm{a}}$ & $38.0^{\mathrm{a}}$ & $38.8^{\mathrm{b}}$ & $39.0^{\mathrm{b}}$ & $38.5^{\mathrm{b}}$ & 0.6 & $*$ & ns \\
\hline Blockiness index & $0.29^{\mathrm{a}}$ & $0.33^{\mathrm{b}}$ & $0.32^{\mathrm{b}}$ & $0.30^{\text {ba }}$ & $0.38^{\mathrm{c}}$ & $0.37^{\mathrm{c}}$ & 0.01 & $* * *$ & $* * *$ \\
\hline L.D. area $\left(\mathrm{cm}^{2}\right)$ & $8.4^{\mathrm{a}}$ & 8.2 & 8.4 & 8.0 & 8.5 & 8.3 & 0.49 & ns & ns \\
\hline \multicolumn{10}{|c|}{ Tissue composition (6th rib) } \\
\hline Rib weight (g) & $177.5^{\mathrm{a}}$ & $203.1^{\mathrm{b}}$ & $200.5^{\mathrm{b}}$ & $201.1^{\mathrm{b}}$ & $231.4^{\mathrm{c}}$ & $221.5^{c}$ & 6.92 & $* * *$ & $* * *$ \\
\hline Muscle (g) & $118.9^{\mathrm{a}}$ & $145.8^{\mathrm{b}}$ & $141.0^{\mathrm{b}}$ & $149.1^{\mathrm{bc}}$ & $156.4^{\mathrm{c}}$ & $152.4^{\mathrm{c}}$ & 5.37 & $* * *$ & $* * *$ \\
\hline Subcutaneous fat (g) & $7.8^{\mathrm{a}}$ & $11.4^{\mathrm{b}}$ & $12.5^{\mathrm{b}}$ & $9.3^{\mathrm{a}}$ & $15.7^{\mathrm{c}}$ & $15.9^{\mathrm{c}}$ & 1.92 & ns & $* * *$ \\
\hline Intramuscular fat (g) & $9.2^{\mathrm{a}}$ & $15.4^{\mathrm{b}}$ & $14.7^{\mathrm{b}}$ & $7.3^{\mathrm{a}}$ & $18.2^{\mathrm{c}}$ & $16.5^{\mathrm{b}}$ & 1.64 & ns & $* * *$ \\
\hline Bones (g) & $39.1^{\mathrm{a}}$ & $30.5^{\mathrm{a}}$ & $32.3^{\mathrm{a}}$ & $35.4^{\mathrm{a}}$ & $39.3^{\mathrm{b}}$ & $36.5^{\mathrm{b}}$ & 1.64 & $* * *$ & $*$ \\
\hline Muscle (\%) & $67.0^{\mathrm{a}}$ & $71.8^{\mathrm{b}}$ & $70.8^{\mathrm{b}}$ & $68.2^{\mathrm{a}}$ & $73.0^{\mathrm{b}}$ & $71.1^{\mathrm{b}}$ & 1.36 & ns & $* *$ \\
\hline Bone (\%) & $22.0^{\mathrm{a}}$ & $15.0^{\mathrm{b}}$ & $15.8^{\mathrm{b}}$ & $17.7^{\mathrm{a}}$ & $16.0^{\mathrm{a}}$ & $16.5^{\mathrm{a}}$ & 0.61 & ns & $*$ \\
\hline Total fat (\%) & $9.8^{\mathrm{a}}$ & $13.2^{\mathrm{b}}$ & $13.4^{\mathrm{b}}$ & $8.1^{\mathrm{a}}$ & $17.0^{\mathrm{b}}$ & $14.7^{\mathrm{b}}$ & 1.4 & ns & $* * *$ \\
\hline
\end{tabular}

T1 (Grazing); T2 (Grazing + a non-molasses based concentrate); T3 (Grazing + molasses based concentrate).

G: genotype effects, T: treatment effects; LD: longissimus dorsi.

${ }^{\text {a-d }}$ Least square means with different superscripts within a row are different $(P<0.05)$. SE: standard error of the mean. ***_ $P<0.001$, **_ $P<0.01$, *- $P<0.05$, ns: non significant.

Supplemented goats had heavier $(P<0.05)$ ribs, more subcutaneous and intramuscular fat and bone weights than grazed goats. On a percentage basis carcasses from supplemented goats had higher $(P<0.05)$ lean and fat percentages, but with lower bone percentage, than grazed goats. Lower muscular development observed in grazed compared to supplemented goats was attributed to higher maintenance energy 
requirements and restricted nutrient supply of unimproved rangeland pastures. Therefore, better carcass characteristics and muscular development observed in supplemented goats indicates that it is possible to change composition of goats' carcasses to comply with consumers' requirements and thus obtain higher market prices.

\section{Conclusion}

Modification of the traditional feeding system through supplementation improved carcass characteristics and composition. Excessive fat deposition in carcasses and a too high use of concentrates may result, and therefore there is need to establish an appropriate age-at-entry to fattening and duration of supplementation when maximum carcass quality is obtained.

\section{Acknowledgements}

The authors are thankful to Danida Fellowship Centre under the ENRECA project "Income Generation through Market access and improved Feed Utilization: Production of quality Beef and Goat Meat (IGMAFU-Meat” Project) and Carnegie of New Yolk for funding this research and manuscript preparation respectively.

\section{References}

Albertì, P.B., Panea, Sańudo, C., Olleta, J.L., Ripoll, G., Ertbjerg, P., Mette, C., Gigli, S., Failla, S., Concetti, S., Hocquette, J.F., Jailler, R., Rudel, S., Reneand, G., Nute, G.R., Richardson, R.I. \& Williams, J.L., 2008. Live weight, body size and carcass characteristics of young bulls of fifteen European breeds. Meat Sci. 114, 19-30.

Casey, N.H. \& Webb, E.C., 2010. Managing goat production for meat quality. Small Rumin Res. 89, 218-224.

Chacón, E., Macedo, F., Velázquez, F., Rezende, P.S., Pineda, E. \& Concepta-McManus, C., 2011. Morphological measurements and body indices for Cuban Creole goats and their crossbreds. R. Bras. Zootec. 40, 1671-1679.

De Boer, H., Dumont, B.L., Pomeroy, R.W. \& Weniger, J.H., 1974. Manual on E.A.A.P. reference methods for assessment of carcass characteristics in cattle. Livest. Prod. Sci. 1, 151-164.

Devendra, C. \& McLeroy, G.B., 1982. Goat and Sheep Production in the Tropics. Intermediate Trop Agric Series. pp. 29.

Devendra, C. \& Owens, J.E., 1983. Quantitantive and qualitative aspects of meat production from goats. Wrld Anim. Rev. 47, 19-29.

FAO, 2004. The state of the World's Animal Genetic Resources (SoW-AnGR) Report. Food and Agriculture Organizations, Rome, Italy. February, 2004.

Johnson, E.R. \& Baker, D.A., 1997. Use of linear measurements of m. longissimus to predict the muscle content of beef carcasses. Meat Sci. 45, 321-327.

Mahgoub, O., Kadim, I.T. \& Webb, E.C., 2012. Goat Meat Production. CABI, Nosworthy Way, Oxfordshire, UK.

Okello, K.L. \& Obwolo, M.J., 1984. Uganda. Review of the potentialities of goat production. Wrld Anim. Rev. 53, 27-32. http://www.fao.org.

Okello, K.L., Ebong, C. \& Opunda-Asib, J., 2004. Effect of feed supplements on weight gain and carcass characteristics of intact male Mubende goats fed elephant grass (Pennisetum purpureum) ad libitum in Uganda. J. Anim. Vet. Adv. 8, 2004-2008.

Robelin, J., Geay, Y. \& Beranger, C., 1974. Estimation de la composition de la composition des carcasses

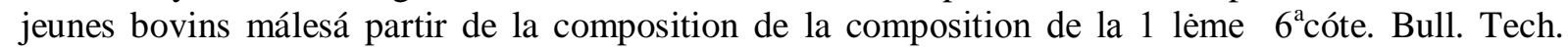
CRZV INRA Theix, 17, 15-18.

Ryan, S.M., Unruh, J.A., Corrigan, M.E., Drouillard, J.S. \& Seyfert, M., 2007. Effects of concentrate level on carcass traits of Boer crossbred goats. Small Rumin. Res. 73, 67-76.

Safari, J., Mushi, D.E., Mtenga, L.A., Kifaro, G.C. \& Eik, L.O., 2009. Effects of concentrate supplementation on carcass and meat quality attributes of feedlot finished Small East African goats. Livest. Sci. 125, 66-274. 
SAS, 2001. Statistical Analytical Systems SAS/SAT Release 4th Ed. SAS Institute Inc., Cary, North Carolina, USA.

Simela, L., Webb, E.C. \& Bosman, M.J.C., 2011. Live animal and carcass characteristics of South African indigenous goats. S. Afr. J. Anim. Sci. 41, 1-15.

Steyn, J., 2010. A practical guide for southern African conditions. Boer goats - South Africa. www.boergoats.co.za. Site visited on $3^{\text {rd }}$ January 2013. 